Rev. Elev. Méd. vét. Pays trop., 1970, 23 (4): 425-30

\title{
Culture et titrage du virus de la Maladie de Newcastle sur des cellules Vero
}

\author{
par NGUYEN - BA-VY (*) \\ (avec la collaboration technique de Mlle M. OREN)
}

\begin{abstract}
RESUME
Onze souches de virus de la maladie de Newcastle ont été cultivées sur des cellules de la lignée Vero, où il est apparu des lésions cytopathiques, des syncitia, des inclusions intracytoplasmiques et des phénomènes d'hémadsorption. Les titrages du virus et des antisérums, effectués sur ces cellules, ont donné des titres plus bas que ceux obtenus sur des ceufs embryonnés. Par contre ces deux méthodes ont permis le même nombre d'isolements positifs du virus à partir des prélèvements suspects.
\end{abstract}

La culture et le titrage du virus de la maladie de Newcastle se font habituellement sur des œufs embryonnés, mais l'approvisionnement en cufs de bonne qualité pose souvent des problèmes délicats aux laboratoires situés loin des centres avicoles. Les résultats des titrages peuvent devenir irréguliers par la présence éventuelle dans les cufs de microorganismes ou d'anticorps spécifiques provenant des poules vaccinées ou infectées. Pour remédier à ces inconvénients, on a pensé à l'usage des cultures cellulaires: des cellules d'origine aviaire (5) (7) (9), bovine (1), humaine (4) (6), porcine (12), simienne (3) (1), ou des cellules de lignée continue : Hela (2) (13), Hep. 2 (6), KB (10) (11), PK $15, \mathrm{MS}$, $\mathrm{BHK}_{21}$ (8). La préparation des cellules d'explantation demande du temps et leur sensibilité varie d'un lot à l'autre. Les cellules de lignée continue sont disponibles plus rapidement. Cependant il faut trouver des souches sensibles à l'égard du virus de la maladie de Newcastle, réagissant par de nettes lésions

(*) Laboratoire de Virologie, Institut d'Elevage et de Médecine vétérinaire des Pays tropicaux, 10, rue Pierre Curie, Maisons-Alfort (Val de Marne). cytopathiques ou par une hémadsorption spécifique.

Dans cet article, nous exposons les résultats des cultures et des titrages de plusieurs souches de ce virus sur une lignée continue de cellules rénales de singe vert (Cercopithecus aethiops), la souche Vero (14).

\section{MATERIEL ET TECHNIQUES}

\section{Culture cellulaire}

Le milieu de culture est à base d'hydrolysat de lactalbumine (Difco) à 0,5 p. 100 dans la solution saline d'Earle, additionné de $0,01 \mathrm{p}$. 100 d'extrait de levure (Difco), de 0,01 p. 100 de L- glutamine, de 0,01 p. 100 d'acide L- glutamique, de 0,015 p. 100 de L- méthionine, de 0,004 p. 100 de L- arginine chlorhydrate, de 0,0001 p. 100 de Biotine, de 0,0001 p. 100 d'acide folique et de 10 p. 100 de sérum de veau. Le milieu d'entretien ne contient pas de sérum. Le milieu pour la technique de plages est à double concentration et il sera mélangé au moment de l'emploi avec un égal volume d'une solution de gélose (Bacto Agar, Difco) à 2,7 p. 100 . 


\section{Souches de virus}

Onze souches de virus de la maladie de Newcastle (Hitchner, Komarov, Lasota, Algérie, Ambato, Malagasy, Maurice, Niamey, $\mathrm{Pa}$ kistan, Perdrix, Toulouse), sont conservées sous forme lyophilisée. Quelques jours avant leur emploi, chacune est inoculée à des oufs embryonnés de 9 jours; au bout de 48 heures d'incubation à $36^{\circ} \mathrm{C}$ les liquides allantoïdiens sont récoltés, testés par l'hémagglutination et conservés à $-30^{\circ} \mathrm{C}$ jusqu'aux titrages.

\section{Titrages comparatifs du virus}

Les suspensions virales sont diluées selon la progression décimale avec de la solution saline de HANKS. Chaque dilution est inoculée à la dose de $0,2 \mathrm{ml}$, simultanément à 5 tubes de cellules et 5 cufs embryonnés qui seront examinés tous les jours. Les liquides allantoïdiens des oufs ayant leur embryon mort à partir de la $48^{\mathrm{e}}$ heure sont testés par hémagglutination; les tubes de cellules présentant des lésions cytopathiques sont soumis à l'hémadsorption. La lecture finale se fait au $5^{\mathrm{e}}$ jour pour les oufs morts ou vivants et au $8^{\mathrm{c}}$ jour pour les tubes restants. La $\mathrm{DIO}_{50}$ (dose infectante $50 \mathrm{p}$. 100 des cufs) est calculée selon la méthode de REED et MUENCH en comptant ceux qui ont une hémagglutination positive. $\mathrm{La} \mathrm{DICC}_{\tilde{5} 0}$ (dose infectante 50 p. 100 des cultures cellulaires) s’obtient par la même méthode.

\section{Titrages comparatifs des antisérums}

Les antisérums, inactivés à $56^{\circ} \mathrm{C}$ pendant 30 minutes, sont dilués avec de la solution saline de Hanks selon la progression de raison 2 à partir de 1/10. On mélange chaque dilution avec un égal volume de suspension de virus contenant respectivement soit $1.000 \mathrm{DIO}_{50}$, soit 1.000 DICC $_{50}$ par millitre. Après une incubation d'une heure à la température du laboratoire, chaque mélange est inoculé, à la dose de $0,2 \mathrm{ml}$, soit à 5 oufs embryonnés, soit à 5 tubes de cellules. On effectue la lecture finale au $5^{\mathrm{e}}$ jour pour les ceufs et au $8^{\mathrm{e}}$ jour pour les tubes de cellules.

\section{RESULTATS}

\section{Culture du virus sur des cellules Vero}

Le virus de la maladie de Newcastle se multiplie sur des cultures de cellules Vero sans avoir besoin d'adaptation préalable.
L'effet cytopathique se manifeste par des rétractions avec effilements ou arrondissements des cellules, suivies de leur nécrose et de leur décollement. Il y a formation de syncitia et des inclusions intracytoplasmiques; leur nombre varie non seulement d'une souche à l'autre, mais aussi selon la dose de virus inoculés et la durée de la culture. La souche Toulouse fait apparaître, avec $100 \mathrm{DIO}_{50}$, un grand nombre $d^{\prime}$ inclusions et peu de syncitia vers la $72^{\circ}$ heure d'incubation à $36^{\circ} \mathrm{C}$; au bout de $120 \mathrm{~h}$ on trouve des syncitia en abondance; après $144 \mathrm{~h}$., il ne reste pratiquement que des vestiges cellulaires. Avec $10^{6} \mathrm{DIO}_{50}$, un grand nombre de cellules sont décollées au bout de 24 heures et la nappe cellulaire se disloque rapidement.

Le phénomène de l'hémadsorption sur ces cellules est la propriété la plus régulière et la plus précoce de toutes nos souches de virus. On peut observer, avec un inoculum de $10^{4}$ $\mathrm{DIO}_{50}$, une hémadsorption massive vers la $24^{\circ}$ heure. Il existe cependant de fausses réactions, dues le plus souvent à l'emploi de vieilles suspensions de globules rouges, de tubes de cellules âgées ou à la contamination microbienne de ces derniers. Pour préserver les cellules infectées, durant l'exécution de ce test, il est utile de substituer la solution saline de Hanks à l'eau physiologique comme liquide de rinçage des cultures cellulaires et liquide de suspension des hématies.

La production des hémagglutinines dans les liquides des cultures a été étudiée avec 6 souches de virus; négative au bout de 2 heures après l'inoculation elle augmente progressivement au bout de 72 heures. Les cultures des souches atténuées Hitchner, Lasota et Komarov sont hémagglutinantes à $1 / 4-1 / 8$. Les souches virulentes Algérie, Niamey et Toulouse ont des titres plus élevés, allant jusqu'à $1 / 80-1 / 160$.

La multiplication du virus s'est effectuée dans des flacons de cellules en position stationnaire. Le titre viral d'une culture de 72 heures est de $5 \times 10^{6,5} \mathrm{DIO}_{60}$ par millilitre, pour les souches Algérie, Komarov, Niamey et Toulouse. Les souches Hitchner et Lasota ont des titres plus faibles : $5 \times 10^{4,5}$ et $5 \times 10^{5,5} \mathrm{DIO}_{50 \mathrm{ml}}$.

La technique de plages réalisée sur des nappes de cellules Vero avec les souches Algérie, Komarov, Niamey, Toulouse et Lasota, a fait apparaitre des plages uniformes, bien déli- 


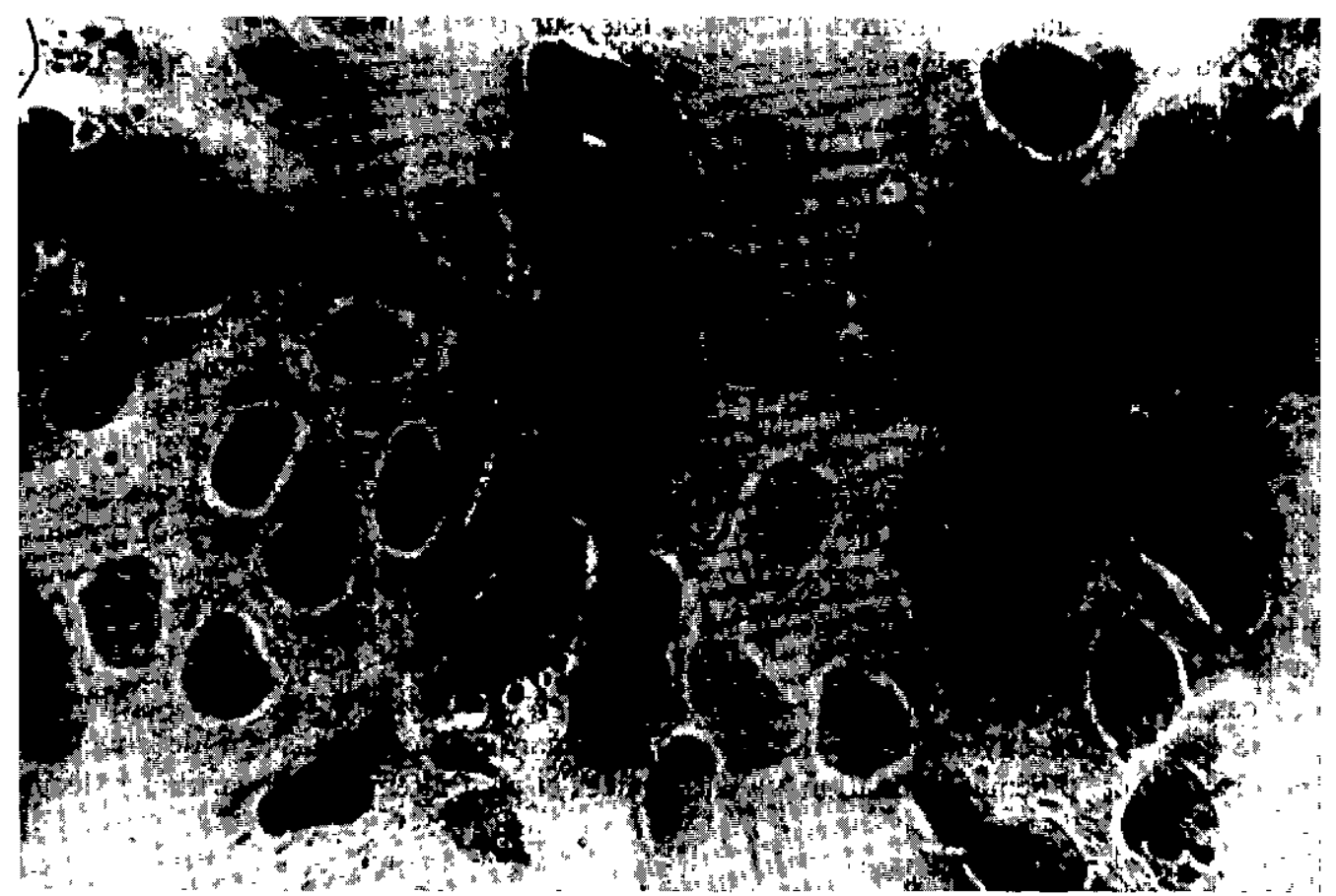

Fig. 1.

Culture du virus de la maladie de Newcastle sur des cellules Vero: formation des inclusions intracytoplasmiques.

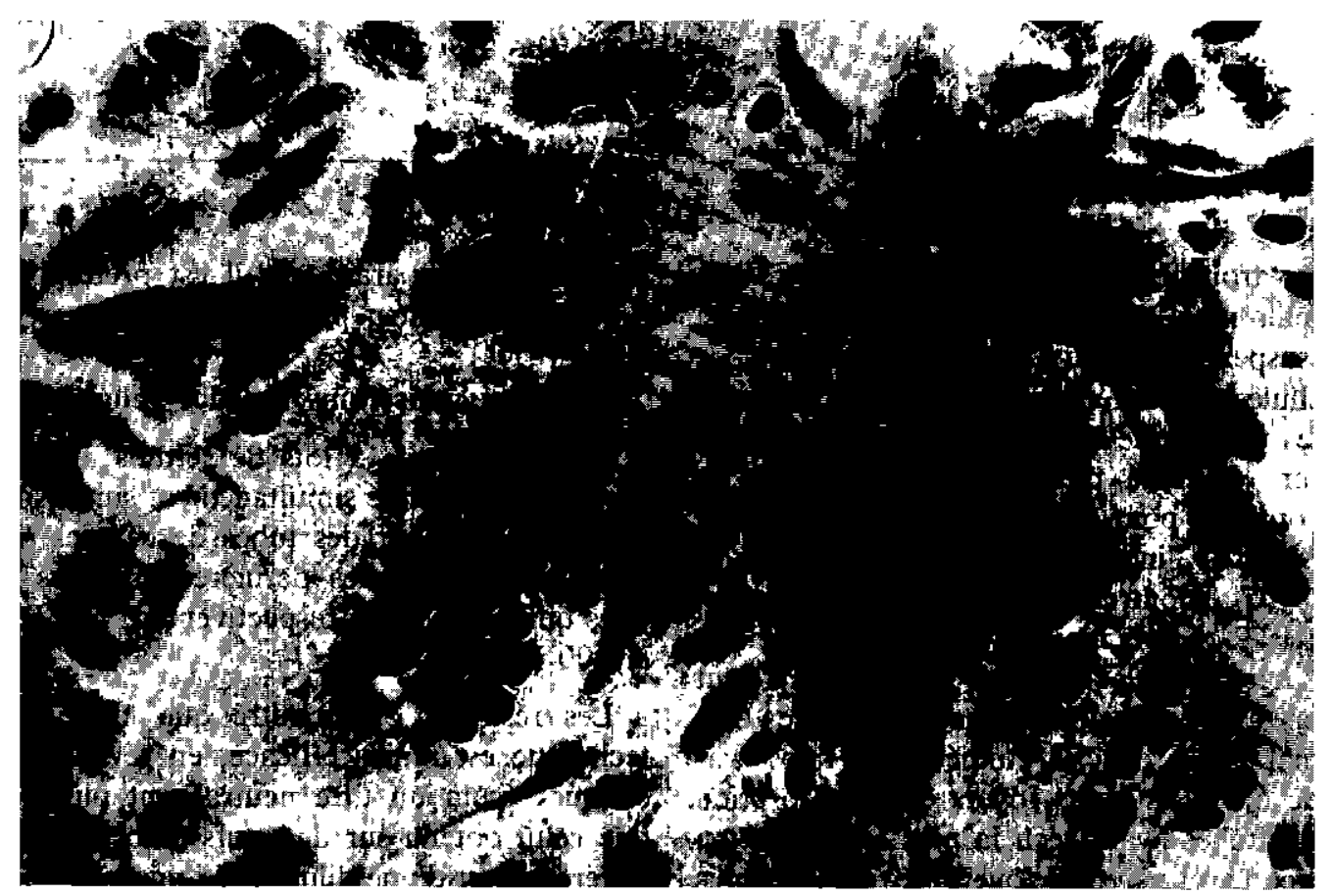

Fig. 2.

Culture du virus de la maladie de Newcastle sur des cellules Vero: formation des syncitia. 
mitées, de $1 \mathrm{~mm}$ de diamètre environ, au bout de 72-96 heures après l'inoculation.

\section{Isolement du virus sur des cellules Vero}

Dans le but de comparer la sensibilité des techniques d'isolement du virus, nous avons inoculé simultanément aux tubes de cellules Vero et aux cufs embryonnés de 9 jours, 8 prélèvements de cerveau, de foie et de rate provenant de volailles atteintes de maladie naturelle et 10 autres appartenant à des sujets morts de maladie expérimentale. Les morceaux de foie et de rate ont été chaque fois broyés ensemble et les cerveaux séparément, avant d'être mis en suspension dans un égal volume de la solution de Hanks additionnée d'antibiotiques. Dans tous ces cas, le virus de la maladie de Newcastle a été détecté respectivement par des tests d'hémadsorption et d'hémagglutination, à la fois sur des cellules Vero et sur des outs embryonnés, dans un délai de 20 à 48 h après l'inoculation.

\section{Titrage du virus sur des cellales Vero}

Les liquides allantoïdiens des cufs inoculés de souches de virus Algérie, Niamey, Toulouse, Hitchner, Komarov et Lasota ont été titrés simultanément sur des tubes de cellules Vero et sur des œufs embryonnés, afin de comparer la sensibilité de ces deux méthodes. Les résultats ont montré que ces cellules sont moins sensibles que les embryons de poules au virus de Newcastle et donnent des titres plus bas que ceux obtenus par ovoculture. Cette différence moins grande avec des scuches virulentes, est bien marquée lorsqu'il s'agit de souches atténuées et peut atteindre 2 logarithmes décimaux.

\begin{tabular}{|l|c|c|c|}
\hline $\begin{array}{c}\text { Souches de } \\
\text { virus }\end{array}$ & \multicolumn{2}{|c|}{ Vero (en DICC ${ }_{50}$ Titrage sur $\left.^{\text {Oeufs (en DIo }}{ }_{50}\right)$} & $\begin{array}{c}\text { Ecarts des } \\
\text { titres }\end{array}$ \\
\hline Hitchner & $5 \times 10^{6,5}$ & $5 \times 10^{8,5}$ & 2 \\
Komarov & $5 \times 10^{5,9}$ & $5 \times 10^{7,9}$ & 2 \\
Lasota & $5 \times 10^{6,1}$ & $5 \times 10^{8,1}$ & 2 \\
Algérie & $5 \times 10^{7,9}$ & $5 \times 10^{8,3}$ & 0,4 \\
Niamey & $5 \times 10^{7,5}$ & $5 \times 10^{8,3}$ & 0,8 \\
Toulouse & $5 \times 10^{7,5}$ & $5 \times 10^{8,3}$ & 0,8 \\
\hline
\end{tabular}

Pour trouver le délai d'obtention du titre maximal, nous avons inoculé chaque dilution de la suspension virale à une quinzaine de tubes de cellules. A différents intervalles de temps, 3 tubes de chaque lot sont testés par l'hémadsorption. Pour la plupart de nos souches le délai optimal pour la lecture finale est de 96 heures après l'inoculation. Les tubes recevant $10^{4} \mathrm{DICC}_{\overline{5} 0}$ montrent une hémadsorption négative à la $2^{\mathrm{e}}$ heure mais nettement positive dès la $20^{\mathrm{e}}$ heure. La lecture vers la $48^{\mathrm{e}}$ heure peut donner une idée approximative sur le titre maximal de la souche étudiée, par l'observation de quelques petits foyers d'hémadsorption dans les tubes ayant reçu la plus forte dilution positive du virus. Ces foyers deviennent plus étendus et plus nombreux au bout de 72 à 96 heures. Lors du titrage de souches très atténuées, comme la souche Hitchner, ils sont plus lents à apparaître et il est préférable de prolonger l'examen pendant 1 semaine.

\section{Titrage des antisérums sur des cellules Vero}

Le titrage de 5 lots de sérums anti-Newcastle a été effectué simultanément sur des cufs embryonnés et sur des tubes de cellules Vero, afin de comparer les dernières dilutions sériques qui neutralisent respectivement $100 \mathrm{DIO}_{50}$ et $100 \mathrm{DICC}_{50}$.

Les résultats ont montré que la deuxième technique est moins efficace, en révélant pour chaque sérum un titre neutralisant plus faible que celui obtenu sur des œufs embryonnés : la différence est d'une dilution de raison 2 dans la plupart des cas. Même en remplaçant, lors de ces titrages, les souches virulentes (Algérie, Niamey et Toulouse) par des souches atténuées 
(Hitchner, Lasota, Komarov) nous ne pouvions pas faire disparaître complètement cette disparité.

\section{COMMENTAIRES}

L'examen prolongé des cultures de virus exige des cellules qui puissent survivre assez longtemps dans un milieu d'entretien. La souche de cellules Vero s'est révélée comme l'une des rares souches de lignée continue dont la nappe cellulaire garde un bon aspect pendant une dizaine de jours, sans avoir besoin de changement du milieu d'entretien.

Nos essais sur un nombre relativement faible de prélèvements, ont montré que l'usage des cellules Vero est aussi intéressant que celui des œufs embryonnés dans la détection du virus de la maladie de Newcastle. Lorsque ces résultats se confirmeront sur un pius grand nombre de cas, nous y trouverons un moyen de diagnostic expérimental plus pratique et moins onéreux que les œufs embryonnés, notamment ceux provenant de pondeuses non vaccinées dont l'acquisition est coûteuse voire impossible dans certaines régions où cette maladie sévit à l'état enzootique, l'usage des œufs provenant des élevages vaccinés ou contaminés pouvant donner des résultats irréguliers lors des titrages du virus ou des antisérums.

L'utilisation des cellules Vero, quoiqu'elle soit moins efficace que celle des cufs embryonnés pourrait être appliquée à la standardisation des vaccins et des immunsérums anti-Newcastle lorsque l'étalonnage a été effectué sur ces mêmes cellules.

\title{
SUMMARY
}

\author{
Growth and titration of Newcastle disease virus in Vero cell culture
}

Eleven strains of Newcastle disease virus have been grown on Vero cell cultures, showing cytopathic lesions, syncitia, intracytoplasmic inclusions and hemadsorption. Virus and antisera titrations assayed in these cell cultures, have given titres lower than those obtained in chick embryonated eggs. However the number of virus positive isolations from suspect samples are similar by these two methods.

\section{RESUMEN}

Cultivo y dosaje del virus de la enfermedad de Newcastle sobre células Vero

Se cultivaron once cepas del virus de la enfermedad de Newcastle sobre células de la cepa Vero, en las cuales aparecieron lesiones citopaticas, syncitia, inclusiones intracitoplasmicas y fenómenos de hemadsorpción. Los dosajes del virus y de los antisueros, efectuados sobre dichas células, daron titulos más bajos que los obtenidos sobre huevos embrionados. En cambio, estos dos métodos permitieron el mismo número de aislamientos positivos del virus a partir de las muestras.

\section{BIBLIOGRAPHIE}

1. ANDRE (J.) et AUDEBAUD (G.), «Culture du virus de Newcastle et applications pratiques", Rapport annuel sur le fonctionnement technique de l'Inst. Pasteur du Vietnam 1959, p. 47.

2. BANKOWSKI (R. A.) et HYDE (J.), «Cultivation and cytopathogenicity of Newcastle disease virus in Hela and bovine kidney cell culture», Amer. J. vet. Res. 1957, 18, 743-746.

3. CHANOCK (R. M.), «Cytopathogenic effect of Newcastle disease virus in monkey kidney cultures and interference with Poliomyelitis viruses », Proc. Soc. Exptl. Biol. Med. 1955, 89, 379-381.
4. CHAPRONIERE (D. A.) et PEREIRA (H. G.), "Propagation of fowl plague and Newcastle disease viruses in cultures of embryonic human lung », Brit. J. Exptl. Pathol. 1955, 36. 607-610.

5. GOLDWASSER (R.) et KOHM (A.). "Neutralization and titration of Newcastle disease virus in chicken embryo tissue culture », Amer. J. vet. Res. 1957, 18, 390-395.

6. GELENCZEI (E.) et BORDT (D.), "Studies of Newcastle disease virus strains in yarious cell cultures", Amer. J. vet. Res 1960, 21, 987-992.

7. MASON (E. J.) et KAUFMAN (N.). « Newcastle disease virus in cultures of chick embryo tissues: 
its multiplication, titration and cytopathogenicity ", Amer J. Path. 1955, 31, 883-889.

8. NGUYEN - BA-VY (travaux inédits).

9. PEREIRA (H. G.) et GOMPELS (A. E. H.), «The growth of fowl plague and Newcastle disease viruses in roller tube cultures \%, J. Pathol. Bacteriol. 1954, 67, 109-115.

10. PIGOURY (L.), MICHEL (C.) et CHABASSOL (C.), * Note sur le pouvoir cytopathogène du virus de la Maladie de Newcastle cultivé sur cellules KB », Ann. Inst. Past. 1952, 103, 443-446.

11. RAMISSE (J.), SERRES (H.) et RAKOTONDRAMARY (E.), «Utilisation des cellules KB pour le diagnostic de la Maladie de Newcastle et le titrage du virus «, Rev. Elev. Méd. vét. Pays trop. 1969, 22. 185-194.

12. SHIMIZU (T.), ISHIZAKI (R.), ISHII (S.), KONO (Y.) et MATUMOTO (M.), \& Multiplication of Newcastle disease and fowl plague viruses in swine kidney tissue culture», Bull. Nat. Inst. Anim. Health. 1957, 33, 42-47.

13. TYRRELL (D. A.J.), "New tissue culture systems for Influenza, Newcastle disease and vaccine viruses $\gg, J$. Immunol. 1955, 74, 293-305.

14. YASUMURA (Y.) et KAWAKITA (Y.), Nihon Rinsho (Tokyo) 1963, 21, 1201. 